\title{
THE ACTANTIAL MODEL AS A TOOL FOR VERTICAL READING OF A DRAMA TEXT
}

\author{
Valentina Nikolovska PhD \\ SOU "Taki Daskalo" - Bitola
}

\begin{abstract}
The aim of this paper is to show that teaching literature requires a creative teacher who would not blindly, immediately and stereotypically just use any kind of method. And the creation is not a random methodical improvisation, but firstly requires thorough theoretical preparation, which will then rip through the practice and will be realized in the famous triad: teacher-literary work-student. The creative teacher uses different forms and methods of teaching which placesthe pupil or the student at the center of learning, that is, he/she applies the principle of polymericity. The model that will be presented with this paper is the actantial model and it consists of six actants or six houses: the subject, the object, the addressee, the recipient, the helper and the opponent. This model has the following positive sides:

- Firstly - because it is impressionable, above all, for dramatic analysis, especially on the coregender categories: character, action, conflict, drama, motivation, etc.;

- The analysis takes into account not only the literary but also the theatrological aspect;

- The model is excellently applicable in the teaching of Macedonian language and literature:

allows group and individual typeof work; stimulates the students' creativity; provides project activities; represents a solid foundation forfruitful debates and debates in which the pupil or the student plays the main role;

- As an effective tool for vertical reading, it opens new theoretical and methodical horizons which are less "visible" in other procedures;

- As a maximum realized "longing for the system" and a run towards linqua pura,the actantial model, supported by mathematical poetics, providesprecise methodological analysis and is suitable for scientific expertise.

The actantial model is not a universal methodical kalaue, as, in fact, any other methodtaken separately, but is a great tool for analyzing the drama text.
\end{abstract}

Keywords: actantial model, actants, mathematical poetics, linqua pura, dramatism.

\section{INTRODUCTION}

The actant model as a strategy for vertical reading of dramatic and prose text, was firstly theoretically described by the famous French structuralist A. Greimas, and methodologically (and methodically) applied by the French theatrologist Anne Ubersfeld. In this model, there is a subject and an object, an addresser, an opponent and an aide whose syntactic functions are obvious and an addressee whose grammatical role is less visible and who, if it can be said, belongs to an earlier sentence or, traditional grammar, "mode annex" 1 .

\footnotetext{
${ }^{1}$ MirjanaMiočinovič, 1981, Moderna meorijadrame, Nolit, Beograd, pages 84-85.
} 
The strongest and the most direct influence on the theoreticians with linguistic orientation is, of course, the Russian formalist and structuralist Vladimir Prop. In his capital work "Morphology of the Tale", a book that "has the status of one of the most popular works in world folklore, a book that counts among the key works of the twentieth century" ${ }^{2}$, analyzing the Russian tales, found that in their structure it can identify permanent elements that he calls functions, thirty-one in number. He also performed theoretical systematization in the sphere of characters, and this, of course, stimulated E. Surio and A. Greimas to construct their models.

According to Anne Ubersfeld: "In the endless differences or other works, a small number of relationships can be discovered between the terms that are much more general than the characters and the plots, and we call them actants" 3 .

The first confirmation of this assumption was given by Vladimir Prop in his book "Morphology of the Tale", using the term dramatis personae (the same meaning Greimass gives the term actant in his analysis of narrative structures).

Having in mind the syntax structure and the inventory of the characters which Prop gave, Greimas created his inventory of six actants that can be easily recognized (sometimes by the similarity of the name) The Prophets dramatis personae.

We can conclude that the inventive model contains all the elements of the Prop's inventory, as Greimas has connected the homologous Prop's characters into one actional category (opponent - adversary, fake hero, assistant - donor, helper), while the hero of Prop is a syncretic figure, he is both a subject and an addressee.

After Prop, but quite apart from him, Surrio gave his catalog of drama features. We can conclude that the relationship between terms that are much more general than the characters and actions Prop calls dramatis personae, Sorio - dramatic functions, and Greimas - actants.

To reach the notion of dramatic functions in Surrio, we first call for his explanation of what is a dramatic situation, which he extensively explained and analyzed in the book "Two Thousand Dramatic Situations", as for that to conclude precisely in the end, i.e. to define it with the following words: "A dramatic situation is a structural figure that at some point in the action forms a certain system of forces: - a system of forces present in the microcosm, in the star center of the theatrical world; a force that embodies, endures or revives the main characters at that moment of action"4.

The scheme of functions in Surrio's work coincides with the Graymasian's model of an actional model or, as Surio says, "These are really the only creation forces of a whole that appear in the form of a horoscope topic, showing the state of the dramatic sky at some point" 5 .

(1)Thematic vector force (Leo 2 ) - in the actantial model the subject;

2 Value to which the thematic power is oriented (Sun $\odot$ ) - in the actantial model - the object;

model;

(3) Arbiter - the donor of the good (Libra $\Omega$ ). There is no such thing in the actantial

4 Possible winner of the good (Earth $\left.{ }^{\dagger}\right)$. In the actantial model adresee A2;

5 Opponent - (Mars $\widehat{\jmath})$. In the actantial model - protagonist;

6 Associate (Moon D). In the actant model - associate of the subject.

\footnotetext{
${ }^{2}$ Vladimir Prop, 2009, “Morphology of the tale”, Makedonska rech, Skopje, page 5.

${ }^{3}$ Miočinovič, MirjanaMiočinovič, 1981, Moderna meorijadrame, Nolit, Beograd, str. 22.

${ }^{4}$ Etjen Surio, 1982, Dvesta hiljada dramskih situacija, Nolit, Beograd,str. 42.

${ }^{5}$ Surio, str. 62.
} 


\section{THE ACTANTIAL MODEL AS A METHODICAL PROCEDURE}

When it comes to drama text, the actantial model offers possibilities for very easy detection of the dramatic action, the dramatic situation, then most importantly for the discovery of the drama conflict without which the dramatic text could not exist, the setting of the motivation, as well as for the ideological aspects . For these reasons, we chose to analyze the drama text in literature teaching.

Before we move on to the methodical possibilities of the actant model, we will briefly dwell on the mathematical method based on Solomon Marcus, theoretically explained in the famous Mathematical Poetics.

Marcus, besides Stan Jansen, most consistently use the language linqua pura as the ideal of many theorists of art. Freed from impressionist and intuitionistic discourses, this method, based on precise invariants expressed by numbers (to recall, the Boolean matrix starts from the numbers one and zero, which denotes the opposition presence - absence), provides opportunities for precise methodological analysis. In this way, the hierarchy of the characters is made according to several parameters (scene presence, pair facing, one charactering facing all the others, the relationship between the scene presence and the total number of situations), the plot and the conflict are determined using the formula, and Jordan Stojanoski PhD applied the Marcus method to examples from the Macedonian bit-social drama and finally gave the following conclusion: "The reason for the unexpected high ranking and the less significant characters and their participation in mass scenes and other medium sequences with a large number of non-random characters (which in the Boolean matrix are counted individually): weddings, sittings, engagements, organized partings, etc.

A problem that the mathematical poetics can not solve is that non-concurrent characters get exactly the same values in all parameters. But it can happen (and it is completely expected!), that two such characters, to have a different actant position although equally ranked. Thus, for example, Ampo and Pozzko ("Chorbadzi Theodos"), although concocting (in all situations participate simultaneously), act as antagonists "6.

He does not deny that Marcus's exact actions can be applied in teachingliterature, such as the hierarchy of characters that can be made by the students themselves at home and presented at the classes scheduled for books discussion. Boolean matrices are also methodically used as visual aids for both the teacher and the student. Boolean matrices, without difficulty, could be made by students, individually or in smaller groups. The Boolean matrix is a reminder of the composition of the plot and is a suitable tool for discussing a certain drama, and also a basis for further research work.

\section{METHODICAL POSSIBILITIES OF THE ACTANTIAL MODEL}

Since we have given a theoretical description of the actant model, we will now see how it can be practically applied in the teaching, in the elaboration of dramatic texts.

\footnotetext{
${ }^{6}$ Jordan Stojanoski, 2002, Poetics of the Macedonian bit-social drama, Faculty of Pedagogy, Bitola, page 162.
} 
The initial acquaintance of students with the structure of the actant model should be without much theorization! The simplest way is if the teacher briefly acquaints the students with the actantial sentence as a linguistic unit to which one text can be written: a situation, a phenomenon, a picture, an act or a whole drama. For example: Boshko loves Lenche (Begalka), Master Theodos wants to take the vineyard from Arso (MasterTheodos), Spase wants to let Cveta free from the harem of Osman Bey (Macedonian Bloody Wedding), Antigona wants to bury her brother (Antigona), Vojnicki loves Elena (Uncle Vanya), Rodrigo loves Himena (Sid), Estragon wants Godo to arrive (Waiting for Godo), Tartif wants to take the property from Orgon (Tartif). These sentences contain the actional core $\mathrm{S}-\mathrm{O}$, that is, the subject (subject), the predicative (predicate), the object (object) are also a full - featured model.

The other four actants are easily revealed, if the students understand the structure of the model, explained in the previous chapter: the addresser encourages the action of the subject towards the object; the addresser is the actor who is the recipient of the action, i.e. on behalf of whom the action is performed; the assistant assists the subject, and the opponent disables (hinders) his action.

Of course, first the students work together with the teacher who will encourage their research steps, endeavoring not to regard the model as an uncreative scheme.

So, we jointly make the first practical step (after, of course, we will graphically "draw" the model) - filling in the actant places with actors, i.e. characters from the play we analyze. Immediately to note that usually the first phenomena (in S. Jansen and S. Marcus sequences) can be confused by the inexperienced analyst (for example, the student), as they produce dramatic unproductive, even naive models.

Take, for example, a bit of drama, in which the servant carries a gourt with rakia for the Master, the servant serves the mezzes, the housewife greets the guest or simply someone is present on the scene without a replica. Such banal situations will be rejected intuitively until we discover a dramatic productive model, and this requires a thorough, studious reading.

We fill in the precise models, looking for arguments in the text, which we mostly find in the drama speech (dialogue, monologue), but also in the so-called mute situations. Thus, we can get not one, but more models with different subjects. This procedure will be proved by examples from the Sophocles Antigone, which, according to the connoisseurs of ancient and world drama, is a drama with a perfect shape.

We open the Boolean matrix and "read": Antigone and Ismena come out on the stage, then the Choir performs, in the next situation Creon and the Corinthians have a discussion, the Guardian comes on the King's order, etc., From these situations, the students, skillfully guided by their teacher, "discover" that:

- King Edith's sons died in battle for Thebes, fighting on opposite sides;

- Antigone expresses readiness to bury the brother who died as an enemy of the state;

- Ismena is scared, she can not help her sister;

- Creon forbids to bury Polynnik because he died as an enemy warrior ...

These arguments are already sufficient to fill one full-length model: 


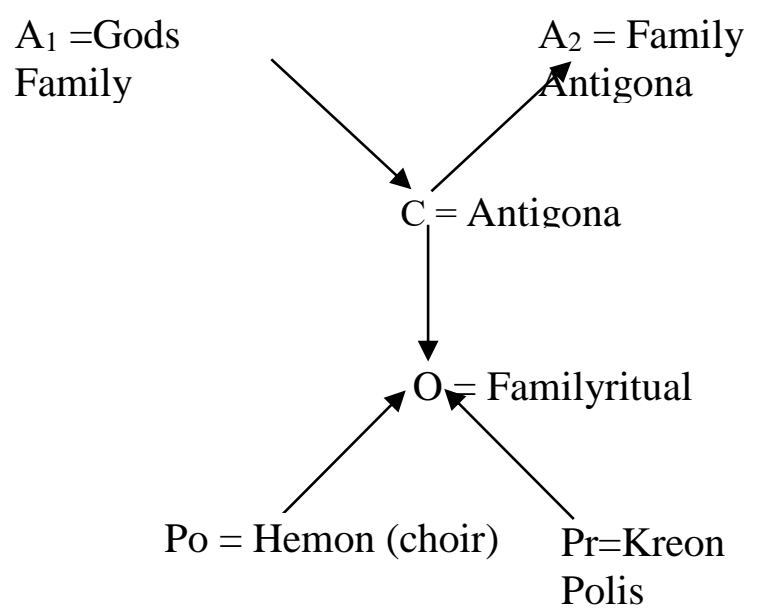

In the text below, we discover something very important: Creon, who is an actantialopponent, appears in the following situations as a subject. To remind ourselves: in order for an actant to be a subject, he/she must have his/her own predicate, object and of course: the addresser, the addressee, the helper, the opponent. Instructively guided by the teacher, the students themselves will "discover" the inventive model with the subject Creon.

The questions addressed to students should be precise and directional. For example: How did Cleon act, when he realized that Polinik died as an enemy? The answer is that he ordered everyone to leave his body to be tornby the beasts. Then, the students should be given reasoning - for the cause of such a cruel procedure. Here is required a more in-depth knowledge of the ancient social order, in order to answer that this order of Creon is not arbitrary, but stems from the laws of the Theban Polis. So - what is the action of Creon? The answer would be that he, as a king, had a duty to protect the law. We get the following actant model with the subject Creon:

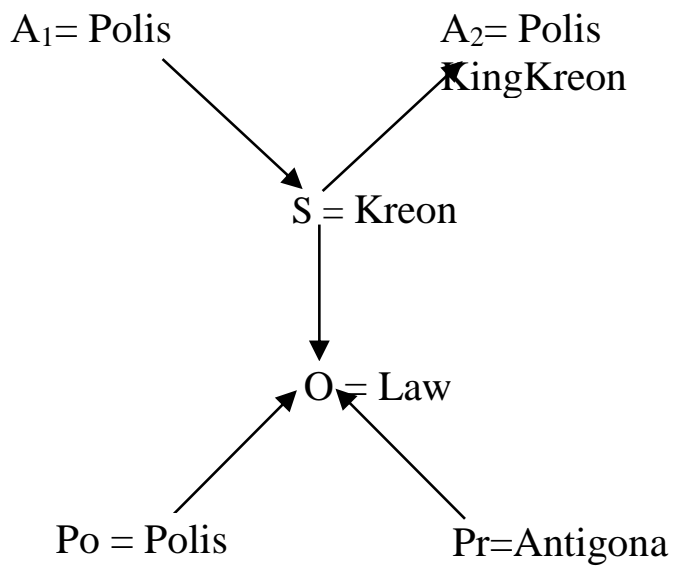

Family

Gods 
The protagonist model with the subject Antigone formulates the sentence phrase or reads like this: (Antigona wants to bury her brother, motivated by the family and the Gods, Helen helps her, the enemy is Creon, and the winner is the family and Antigona) .

The actantial model with the subject Creon formulates the actant's sentence or "should be read" this way: (Creon wants to protect the law, motivated by the Theban polis who is his assistant, but Antigone, the family and the gods are opposed to it, and the winners are Theban Polis and Creon).

\section{CONCLUSION}

The positive aspects on the application of the concrete model in the teaching of Macedonian language are:

A) Encouraging the knowledge and skills for an in-depth analysis of the drama text.

a) The Actantial model allows vertical reading of the dramatic text. And this means one qualitative and inventive breakthrough of the student in the structure of the play. Studies have unequivocally demonstrated that after the initial theoretical aporia ${ }^{7}$, the students gradually, step by step, adopted the "mechanism" of the actantial model and after several prominent exercises they were already trained to "record" the dramatic situations with their acronyms, and then read them as actant sentences.

It was found that the actational analysis of the drama text through the so-called " triangles "visualize" the abstract concepts so students disclose them in the text.

b) Thus, the category of action (without which it is impossible to define the drama as a genre) perceived in the relation subject-object; could "read" it from the model, and also write it down (of course, those who read the drama).

c) The students can understand the motivation of the characters as a psychological category, that is, as the character is a living individual. Actual analysis, especially if it is broken down into the so-called psychological triangle, eliminates this naive image of the character as a person of reality and points to the world of fiction which is a closed and autonomous world with laws that are not subject to the verification of the laws of reality. Analysis of the so-called a psychological triangle instructs the teacher how to enter the world of characters without falling into a naïve phyllitic interpretation, in which the character interferes with the prototype, the fiction with reality.

d) Familiarizing with the so-called. ideological triangle, students enter the essence of the theater. And this theatrological field is almost completely absent in the teaching of Macedonian language and literature, because the drama is analyzed above all as a text!

e) Students quickly grasp the so-called conflict (or dramatic) triangle: subject-object-opponent and can write a dramatic situation with the usual abbreviations for actors and fill it with specific

\footnotetext{
${ }^{7}$ aporia - a statement which is logical, but opposes our logic; there was a rebellion among students from the abstract theoretical structures, but the duration of that rebellion was about 3-4 minutes or by the reading of the first actantial sentence, the illogic and the rebellion disappeared.
} 
characters and then discuss. Students analyze the active triangle by adopting the category of drama that is fundamental for the genre.

B) Developing and improving students' ability to design actantial models.

C) Developing and improving the ability to produce a Boolean matrix.

D) Develop creative abilities and critical thinking.

E) Develop creative abilities and critical thinking beyond the framework of the dramatic content, whereby students can use part of the knowledge acquired in the Macedonian language classes and literature in practical situations in many troubled life situations in which they would be wiser and winners or the educational goals could be implemented or would be realized as functional goals. A typical example of these abilities is the debate, the controversy for the play "Antigone" as a project activity. The actant model is associated with the socio-cultural code and gets the true meaning through the question of the holiness of the family versus the question of the holiness of the defense of the country or the motherland.

b) Reassessing their own and others' attitudes (through discussions and debates that arise in the analysis with the actantial model, students are questioning where they are with their thoughts and attitudes and, in that way, they are able to influence each other, to perceive their mistakes, hear the other's opinion, respect it, but also accept it, if it is more appropriate, wiser and more justified, if it abounds with facts and vice versa to convince the opposing party in their opinion if it is more appropriate, wiser and more justified and if it is abundant with the relevant facts.

\section{BIBLIOGRPHY}

1.Vangelov, Atanas. Theory of prose, Detska Radost, Skopje, year.

2. Nikolovska, Valentina. Doctoral dissertation, Actantial model in

teaching Macedonian language and literature, Pedagogical faculty, Bitola, 2018.

3.Prop, Vladimir. Morphology of the Tale, Makedonska Rech, Skopje, 2009.

4. Stojanovski, Jordan. Poetics of Macedonian Bit - social drama,

University "St. Kliment Ohridski ", Pedagogical Faculty, Bitola, 2002.

5.Lotman, J. Structure of Artistic Text, Belgrade, Nolit, 1976.

6.Markus, Solomon. Mathematical poetics, Belgrade, Nolit, 1974.

7.Miočinović, Mirjana. Modern Theory of Drama, Belgrade, Nolit, 1974.

8. Surio, Etjen. Two hundred thousand dramatic situations, Belgrade, Nolit, 1982.

9. Skreb, Zdenko. Introduction to Literature 